$c$ is the apodeme behind the 1st maxilla; $b$ and $c$ together furm the area of subsidence described in the text which gives rise to the great fold commencing the endophragmal system of Astacus anteriorly.

Fig. 3. The same, four sections further in towards the median plane.

Fig. 4. The same, three sections further in than 3 .

$d$ and $f$, apodemes between $m^{\prime \prime}$ and the 1st trunk-limb, and between the 1st and 2nd trunk-limbs. In Astacus $f$ has been drawn to the position marked $f^{\prime}$, as shown in :-

Fig. 5. The same, five sections further in than 4 .

Fig. 6. Seven sections further in than 5. The gnathobases are seen as distinct appendages; the anterior trunk apodemes are no longer visible, only the large one, behind the underlip, which forms the support of the sternal plate and the anterior attachment for the longitudinal musculature, remains. In the specimen these muscles had been torn from the apodeme, as shown in the drawings. The apodemes which are still visible in the posterior segments are clearly seen to have travelled backward so as to come nearly over the segmental constrictions posterior to those to which they properly belong. This gives us the posterior branch of the endopleurite of Astacus ( $c f$. text).

e, eggs in the genital tube.

Fig. 7. A nearly median section.

$n$, the ventral cord thrown into slight waves by the ventral constrictions.

$m$, teeth of the mandibles.

$\propto$, the œsophagus.

$m g$, the wall of midgut.

$s p$, the median portion of the sternal plate which binds the two apodemes behind the underlip across the middle line. The underlip is represented by the ridge $l$. It is to be noticed that no muscles run into the underlip excepting here, close to the median plane. These bands may have originally formed the true anterior ends of the ventral longitudinal muscles.

IX.-On a new Genus of Oligochata, comprising Five new Species, belonging to the Family Ocnerodrilidæ. By Frank E. Beddard, M.A., F.R.S., Prosector to the Zoological Society of Jondon.

[Plates VI. \& VII.]

Contents.

I. Introductory, p. 74 .

II. Description of five new Species of Gordiodrilus, p. 75.

III. Diagroses of Genus and Species, p. 93.

IV. Affinities of the Genus Gordiodrilus, p. 96.

V. Explanation of Plates, p. 97.

\title{
I. INTRODUCTORY.
}

THE material upon which the present paper is based consisted of a large number of living worms, all of which I received, through the kindness of the Dire ctor of the Royal 
Gardens, from Kew ; these specimens were all carefully preserved for purposes of section-cutting, the only method of studying small worms which are not large enough for dissecting, and which are too opaque to admit of examination while alive. I have invariably made longitudinal sections of the anterior twenty segments or so, which I believe to be much more satisfactory than transverse sections. This method is equally good for the purpose of studying the histology of the organs, and is of course far better than the methol of transverse sections for fixing with precision the position of the various organs-so important a point in Annelid anatomy.

There are not many groups of animals now in which it is possible to find in a few months, and as it were accidentally, four new species, constituting a well-marked new genus. The fact that during the year 1890 forty-eight new species and twelve new genera were described by only eight naturalists with no special facilities (except in the case of one) for collecting, shows that much remains to be done before this group of Annelids is anything like exhausted. And, moreover, most of these new species do not differ merely by some trifling external character, of no interest except to the systematist, but show for the most part important anatomical differences often of more than merely classificatory interest.

The five new species, of which I give an account here, were all found in the earth in which tropical plants had been imported to the Kew Botanical Gardens. Seeing that this accidental transference of worms from one country to another is so easy, it behoves one to be very careful in drawing conclusions as to the geographical distribution of the group.

I place this new genus near to Ocnerodrilus, and, on account of certain peculiarities in the first species, name it Gordiodrilus.

\section{Description of five new Species of Gordiodrilus.}

In the following account I have endeavoured to avoid any unnecessary repetition; where any organ presents exactly the same structure in all species, I have only described it once in detail.

\section{Gordiodrilus tenuis, sp. n. (Pl. VII. fig. 6 C.)}

The material consisted of one specimen only from Assaba, on the west coast of Africa.

The worm was during life extraordinarily thin and active in its movements; its general appearance was suggestive rather of a Lumbriculid or a Phreoryctes, particularly of the latter genus. 
The resemblance to Phreoryctes naturally implies a likeness to the Nematoid Gordius. This resemblance, which was not lost after preservation with Perenyi's solution, followed by alcobol, is due to the very great length of the worm as compared with its breadth. Gordiodrilus tenuis can perform a feat which needs a considerable length of body: the specimen under consideration had actually tied its body into a knot; this suggested the generic name.

A special point of resemblance to Phreoryctes is the great length of the segments as compared with their breadth; the length is equal to, or even exceeds, the diameter; and this statement, it should be observed, applies not only to the living worm, but also to the worm after preservation with reagents that cause a considerable amount of contraction.

Another remarkable characteristic of this annelid was first appreciated when it was lifted out of the basin of water in which it had been placed to thoroughly free it from soil. Under these circumstances the setæ were very distinctly felt for so slender a worm ; it clung to the fingers, and was only with some little difficulty to be detached. This is due, as I shall point out later, to the large size of the ventral setæ. The colour during life was of a creamy white diversified with red marks (the larger blood-vessels) ; there appeared to be no pigment in the skin; the white colour is due to the colomic corpuscles, which are exceedingly numerous. In examining a collection of Oligochæta from tropical Africa, one is inclined to assume that they will prove to belong to the family Eudrilidæ, which is so characteristically an African family; and as a matter of fact, all the other specimens which I received from Assaba along with this Gordiodrilus do belong to that family. After the first superficial examination of the Annelid at present under consideration I was disposed to refer it to the genus Megachata, lately described by Michaelsen in one of the most interesting of his many contributions to the structure and distribution of the Oligochæta *. Of Megachata tenuis, one of the two species of the genus, Michaelsen remarks that it is "der schlankeste Teleudriline, der mir zu Gesicht gekommen ist. Das vorhandene aus 162 Segmenten bestehende Stück ist $120 \mathrm{~mm}$. lang bei einer grösste Dicke von nur $1 \mathrm{~mm} . "$ (p. 17). It shows, furthermore, a great disparity in size between the ventral and dorsal setæ; in fact, anyone judging from external characters only would undoubtedly refer my Gordiodrilus tenuis to Michaelsen's genus Megachata. This is, however, only another

* "Beschreibung der von Herrn Stuhlmann auf Sansibar und dem gegenueberliegenden," \&c., SB. Hamb. Wiss. Aust. Bd. ix. 
instance of how impossible it is, in this group of animals, to determine affinities by the outside only; alike as they are superficially, it is not much, if any, exaggeration to say that few genera are structurally farther apart than Gordiodivilus and Megachata. If there were any scope for the action of natural selection in this direction, some might regard this resemblance as an instance of the phenomenon known as "mimicry." It is, however, difficult to see in what way one kind of worm would be advantaged in resembling another, as the characters are not so striking as to appeal to the eyesight of the natural friends or foes of either.

The length of Gordiodrilus tenuis after preservation was about 90 millim., the breadth 1 millim.; the body was bent into a spiral, which I have never noticed except in the long and thin aquatic worms.

\section{E'xternal Characters.}

An examination of a portion of the body-wall mounted in glycerine shows the reason for the curious way in which the worm clings to the finger when handled. Some of the setex are very large; if the body-wall be examined with a lens only, there appear to be only two pairs to each segment. A more careful examination, however, shows that the normal four pairs are present in each segment of the body, with the exception, of course, of the first; the lateral pairs are so small as to escape observation, owing to the eye being accustomed to the large ventral setæ, unless a moderately high magnifying-power is used. The setæ are strictly paired, and the lateral setæ are about a quarter of the bulk of the ventral setæ; the latter are, however, not absolutely of the same size; the innermost seta of each pair is rather larger than the outermost. There is nothing unusual in the shape of these setæ; they have the sigmoid form so generally met with among the Oligochæta, but the tip is perhaps slightly more hooked than is ordinarily the case; this is no doubt partially a cause of the tenacious way in which the worm clings to the finger. Among worms which have sigmoid setæ in both dorsal and ventral bundles (Phreoryctes, Lumbriculidæ, nearly ail "earthworms"), it is by no means common to find such a great difference in size as that which has been recorded in Gordiodrilus tenuis. There are, however, several forms where a like difference does occur. In Phreoryctes, for instance, which has besides a certain superficial similarity to Gordiodrilus, there is commonly a similar inequality in size between the dorsal and ventral setæ. In 
P. Smithii the dorsal are the larger, but in P. Heydeni Noll * figures the ventral setæ $\dagger$ as being slightly the larger, and in P. emissarius $\ddagger$ the dorsal setæ diminish in size posteriorly and finally disappear. In Megachata there is a still closer resemblance to Gordiodrilus tenuis, for the two ventral setæ are not only larger than the dorsal, but the individual setæ of each ventral pair are unequal in size, the innermost of the two being distinctly the larger. But there is also a regular and progressive increase in size, affecting not only the ventral, but also the lateral setæ, Even in Perichata, with the circle of numerous setæ in each segment, the ventralmost ones are in a few cases $(e . g$. in $P$. Houlleti) decidedly larger than the rest. These cases are interesting as showing the differentiation of a dorsal and ventral surface, which, so far as the setæ are concerned, is not always apparent in the Oligochæta. It would add to the interest if it could be ascertained whether there is any corresponding modification of habit ; whether, for example, Megachceta and Gordiodrilus frequent the surface of the soil rather than its depths.

The clitellum was not apparent until the worm was examined by means of sections. It is very extensive, reaching from the xivth to about the xxviith segment, and is only developed dorsally.

I could not find any dorsal pores.

The nephridiopores open in front of the lateral setæ.

\section{Internal Structure.}

Having only one specimen of this Oligochæte for examination, I am not able to give so complete an account of Gordiodrilus tenuis as I could wish, and as I have been able to give concerning the other species of the genus. My account is, moreover, rendered less complete than it would otherwise have been by the fact that the sections were in many places insufficiently stained. Nevertheless I have been able to make out the principal facts which bear upon the systematic position of the Annelid. The thickness of the cuticle was very remarkable; it appeared to me to be proportionately thicker than in any earthworm which I have

* "Ueber einen neuen Ringelwurm des Rheins," Arch. f. Naturg. Jahrg. 40, p. 260.

† There is a little confusion about this matter. Claparède's Nemodrilus filiformis, which Vejdovsky believes to be identical with Noll's $P$. Heydeni, is stated to have longer dorsal setæ by both Claparède and Vejdovsliy, though Claparède's figures show the reverse.

f Forbes, "On an Anerican Earth worm of the Family Phreoryctidæ," Bull. Illin. Lab. vol. iii. p. 107. 
examined. The colom was crowded with corpuscles, which appeared, however, to be chiefly compacted together to form an investment for the nephridia.

The presence or the absence of an abundant coating of glandular peritoneal cells upon the nephridia no longer distinguishes "earthworms" from "waterworms." Although the majority of the latter have the nephridia covered with large clear vesicular cells ("globules incolores" Claparède calls them), they are occasionally replaced by a thin layer of flattened peritoneal cells. On the other hand, in Phreoryctes the "glandular" investment of the nephridia attains very great dimensions. In earthworms the rule is perhaps for the nephridia to be coated with only a thin layer of peritoneum. Perrier was the first * to draw attention to the fact that in this group also there is no uniformity; for in Pontodrilus an investment of the nephridia occurs which is fully as thick as that which covers the nephridia of Phreoryctes. The Eudrilidæ nearly all show this structural peculiarity; for example, Libyodritus $\dagger$ and Megachota $\ddagger$. In Ocnerodrilus, which I regard as the nearest ally of Gordiodrilus, the nephridia have been described by me $\S$ as partly imbedded in a huge mass of clear cells. These cells are often (e.g. in Heliodrilus, Hyperiodrilus, and Libyodrilus) loaded with spherical bodies, which are probably to be regarded as excretory products. But in that case the accumulation of such cells round the nephridia-themselves excretory organs, seems to be superfluous. Kükenthal \|, however, is of opinion that these "lymphoid cells" are related rather to the blood-vessels than to the organs (e.g. the nephridia) which they and the blood-vessels cover. So far as concerns the nephridia in the Eudrilidæ, there is no objection to this view. But in Ocnerodrilus the nephridia have no blood-vessels, and yet an abundant covering of the cells in question occurs. Kükenthal believes that these cells extract waste products from the blood, and finally breaking down in the colom set free their accumulated stores of excreted matter which reach the exterior via the nephridia; this, of course, only applies to the lymph-cells with brown granular contents which clothe the

* "Etudes sur l'organisation des Lombriciens terrestres: IV. Organisation des Pontodrilus (E. P.)," Arch. d. Zool. Exp. t. ix. p. 205.

$\dagger$ Beddard, "On the Structure of an Earthworm allied to Nemertodrilus," \&c., Quart. Journ. Micr. Sci. vol. xxxii. p. 5554.

I Michaelsen, loc. cit.

\$ "On the Anatomy of Ocnerodrilus (Eisen)," Trans. Roy. Soc. Edinb. vol. xxxvi. pt. ii. p. 563.

II "Ueber die lymphoiden Zellen der Anneliden," Jen. Zeitschr. Bd. xviii. p. 319. 
dorsal vessel and its branches; the relationship of the peritoneal cells to the other blood-vessels is supposed to be rather to the advantage of the cells than of the blood; the cells grow and multiply, and then break off to perform their useful function in life elsewhere. This, however, does not explain the association of the cells with the nephridia in Gordiodrilus tenuis and in other species. So far as the facts enable a generalization, it seems that heat or damp or both combined are related to the abundance of these cells upon the nephridia. Excretion may be more rapid under these circumstances. When the excretory epithelium-the "drain-pipe " cells-is in action, the products of their activity must be thrown off in every direction, not only into the lumen of the tube. It may be therefore that the peritoneal cells serve as storehouses of this waste matter, which is kept close at hand ready for excretion, instead of being thrown off into the body-cavity and having to be laboriously re-collected. The colom, as in all Oligochæta with the exception of Eolosoma, is divided by septa into chambers corresponding with the external metamerism. Some of the anterior septa, as is also usually the case, are of much greater thickness than the others. This applies to the septa separating segments v.-xii.

With regard to the alimentary canal, there seems in the first place to be no gizzard. The single ventral calciferous gland (the minute structure of which will be described under Gordiodrilus elegans) is present. The intestine has no typhlosole.

The reproductive organs I am fortunately able to describe more completely; there appears to be only a single pair of testes, which occupy the usual position in segment xi. (i.e. attached to the front wall of that segment). Owing to the fact that the intersegmental septa are very much broader than the diameter of the body, the successive septa in the anterior region of the body, as is so frequently the case with the Oligochæta, are placed within each other like a series of cups, the concavity being forward. Owing to this disposition of the septa, which seems to be exaggerated in Gordiodrilus tenuis, the testis of each side is pressed between the septum and the parietes. The septum separating segments $\mathrm{x}$./xi. runs for a considerable distance nearly parallel to the parietes; in the narrow space left between the two the testis is wedged.

The sperm-sacs occupy segments x.-xiii. about; but I have not been able to make out their arrangement very clearly; like most of the organs lying in the centre of the body, they were but slightly stained.

The vas deferens like the testis is single on each side of 
the body; each vas deferens commences with a very large funnel which reaches from top to bottom of the cavity of segment xi.; the tube arising from this passes back closely adherent to the ventral parietes and opens on to the exterior in the xith segment, not far behind the septum which separates that segment from the one in front. The external orifice is therefore in front of the setæ of the segment, and to the outside of the ventral couples.

There is nothing that calls for special remark in the minute structure of the vasa deferentia; they are formed of the usual cubical cells, which are ciliated. At the external aperture there is no glandular body connected with the vas deferens, nor are there any modified setæ of any kind. The great length of the vasa deferentia is rather unusual; it is not often that these tubes occupy so many as ten segments, though occasionally they may be even longer than in the present species. Although the vasa deferentia are entirely unconnected at their external orifice with any glandular bodies, a pair of tubular glands open on to the exterior on each side in the immediate neighbourhood of the male pores.

The tubular form of these glands, and the fact that there is a pair of them on each side of the body-one in front of and one behind the male pores-recalls the very characteristic arrangement met with in the family Acanthodrilidæ, and hitherto only found in that family *. But although there is this general similarity, there is also an important difference, namely that the atria, as I may term them, open on to two consecutive segments in Gordiodrilus tenuis. These segments are $\mathrm{xx}$. and $\mathrm{xxi}$.

In the Acanthodrilidæ the atria are, as I myself was the first to point out, quite independent of the vasa deferentia; but they open nearly invariably $\dagger$ on to the xviith and xixth segments.

The atria extend through several segments; they are, as in Acanthodrilus, bent upon themselves once or twice. The minute structure of the atria is also of interest. As in Acanthodrilus and in other genera in which there are tubular atria, the glands consist of a glandular and a muscular part. The muscular part of the atrium is rather short. The

* Bourne's Perichata Stuarti, which appears to show something of the same kind, requires re-investigation.

+ Perrier (Nouv. Arch. d. Mus. t. viii.) has described the atrial pores of both Acanthodrilus obtusus and A. verticillatus as being upon two consecutive segments; the xixth and xxth in one case the xviith and xviiith in the other.

Ann. \& Mag. N. Hist. Ser. 6. Vol. x. 
glandular part is lined by a single row of glandular cells, which are less stained than the surrounding tissues and are filled with excreted granules. In the Acanthodrilidæ, and, in fact, in all other earthworms with tubular atria, the epithelial lining is divisible into two distinct layers, with cells of a different character in each. The Moniligastridæ are partially at least an exception to this rule; and so too is Ocnerodrilus, one of those forms which stand on the borderline between the "Terricolæ" and the "Limicolæ" of Claparede. The structure of the atria of the last-mentioned genus appears in fact to be exactly similar to that of Gordiodrilus. The reduction of the two layers of epithelium to one may perhaps be regarded as a degeneration, correlated possibly with the small size of the worms; but against this hypothesis is the fact that species quite as small as these have atria with the normal two layers of cells.

The ovaries occupy the usual position in segment xiii.; like the testes they are pressed close against the parietes of the body by the septum separating segments xii./xiii. The oviducts open into the xiiith segment opposite to the ovaries, and on to the exterior upon the xivth segment. There is no receptaculum ovorum. The spermatothecce are two pairs, which are large and oval in form; each narrows abruptly to form a very slender duct of considerable length; there are no diverticula.

\section{Gordiodrilus robustus, sp. n. (Pl. VII. figs. 4, 5, 6 B.)}

I have investigated three specimens of this species; it is a native of Lagos, West Africa. Two individuals were studied by means of longitudinal sections; the third was dissected.

\section{External Characters.}

The species is a small one, measuring only 32 millim. after preservation with Perenyi's fluid, followed by alcohol. The sizes of three of the species of Gordiodrilus described in the present paper are shown in fig. 6 .

The individual of Gordiodrilus robustus selected for measurement consisted of ninety segments. The clitellum extends from the middle of the xiiith to the end of the xviith segment; a narrow median area corresponding to the interspace between the ventral setæ is entirely unmodified. The clitellum is very thick, and stands out from the rest of the body in the living as well as in the preserved worm.

The setæ are strictly paired, and lie upon the ventral surface; the two lateral pairs are separated from each other 
by an approximately equal distance ventrally and dorsally. On the vth, vith, and viith segments the setæ are considerably larger than those which follow. A more marked disparity, however, is seen in the ventral setæ of segments xii. and xiii. These are three or four times as large as the lateral setæ of the same segment, and as the setæ of the preceding and succeeding segments; they give a very marked character to the region of the body where they occur. In their shape they are like the seta of the other segments of the body, which have the usual Lumbricid pattern. No peculiarities distinguish the clitellar setæ; the full number of setæ are present upon the clitellum.

The only apertures that I could distinguish upon the body of an individual cut open and mounted in glycerine were the atrial pores; and these are so little conspicuous that I only observed them after I had ascertained their position by means of sections. There are two pairs of atrial pores; as in the last species, they are upon two consecutive segments; but the segments are the xviith and xviiith. The pores lie just behind and to the outside of the outermost seta of the ventral couple.

Behind the male pores is an oval median papilla upon segment xix.; the epithelium covering this papilla is composed of very tall glandular cells with clear non-staining contents.

\section{Internal Structure.}

Above and behind the pharynx the septal glands are very conspicuous; in the vth, vith, and viith segments they form isolated masses attached to the septa dividing these segments. There is a well-developed gizzard in segment viii. In the ixth segment the single ventral calciferous pouch is placed $*$. It was not very well preserved in the specimens; but its structure appears to be identical with that of the pouch of Gordiodrilus elegans. The septa separating segments v./viii. are very thick; those between segments viii./xii., though thinner, are yet stouter than those which follow. There are two pairs of testes and two pairs of vasa deferentia corresponding to these, which remain separate till just before their external orifice. The testes and funnels of the vasa deferentia are as usual in segments $x$. and xi. The ovaries are in segment xiii., and the oviducts open on to segment xiv.; there are no receptacula ovorum.

* In another specimen, dissected since the above was written, the pouches of segment ix. were paired, though ventral in position; this species is, so far, a connecting-link between Gordiodrilus and Pygmceodrilus. 
The spermatothecæ have a somewhat unusual form. There are two pairs of these organs in segments vii. and viii. The pouch is lined with a single layer of columnar cells, covered by an exceedingly delicate layer of muscles. The pouch was invariably much crumpled; it was filled with an almost homogeneous coagulated mass, in which no sper matozoa could be detected. The pouch communicates with the exterior by a very long and slender duct (see fig. 4); the length of this duct is only paralleled among earthworms by the genus Moniligaster; it has thick muscular walls. The spermatothecæ are quite unprovided with diverticula.

3. Gordiodrilus elegans, sp. n.

(Pl. VI. fig. 1 ; Pl. VII. figs. 6 A, 7.)

From the same locality as that which produced the last species were a number of small slender worms, which I took at first for immature examples of Gordiodrilus robustus. They prove, however, to belong to a distinct though closely allied form.

The principal points of difference apart from the shape concern the spermatothecæ and the alimentary canal.

The pores of the atria and of the vasa deferentia appear also to be on different segments; in the present species they certainly lie upon segments xviii. and xix.: that is to say, the first pair open on to segment xviii., the second pair and the vasa deferentia open, independently of each other, on to segment xix. In Gordiodrilus robustus it is the xviith and xviiith segments which appear to bear these pores; but as the sections were rather broken, owing to the presence of grit in the alimentary canal, I may have made a mistake of one segment.

In any case, this species can be distinguished by the entire absence of a gizzard and by the much shorter duct of the spermatothecæ ( $c f$. figs. 4 and 7 ).

\section{External Characters.}

The shape of Gordiodrilus elegans as compared with the last two species can be seen in fig. 6 ; it is a much more slender worm than $G$. robustus, and is not nearly so long as G. tenuis. As in both these species, the male pores open upon an area which is marked off from the rest of the body. When the body-wall is examined as a flat preparation in glycerine, the area (see fig. 1 ) is seen to be circumscribed by a ridge with an undulating outline. The appearance of this area is at first sight remarkably like the area surrounding 
the male pores of some Eudrilids; and one's first idea about an earthworm coming from tropical Africa is that it must belong to that family. The microscopical examination of this area shows that it is quite unlike anything that occurs in the Eudrilidæ; it is much more like what we find in Benhamia; and Gordiodrilus should possibly be referred to the same family, $i$. e. the Acanthodrilidæ. The male genital pores are, as in the other species of this genus, three on each side; two pairs of atrial pores, and one pair of apertures separate from the atrial pores by which the vasa deferentia open on to the exterior. These pores are situated on the ridge itself, and not on the area which it bounds. The position of the pores is shown in fig. 1. Gordiodrilus robustus is to be distinguished from $G$. elegans no less than from $G$. tenuis by the presence of copulatory papillæ upon segment xix. I could find no trace of such papillæ in the present species. Possibly their absence is to be explained by the strongly developed ridge which I have just described; the sucker-like structure which is thus formed may be sufficient to cause the worms to adhere together during copulation, and render unnecessary any special papillæ performing the same function.

The setæ of the present species are strictly paired and ventral in position. There is no difference in size between the setæ of the dorsal and lateral couples, nor are there any particular segments upon which the setæ are enlarged; in these points Gordiodrilus elegans differs from both its congeners. Furthermore the ventral setæ of segments xviii. and xix. are absent in the fully mature worm, while these same setæ are present in the other species. Neither are there any special penial setæ to take their place. The clitellum occupies segments xiii.-xviii.; it is only developed dorsally and laterally; ventrally there is an area left of which the epithelium is unmodified.

\section{Internal Structure.}

In the anterior part of the body a number of the intersegmental septa are specially thickened; the first of these is that which divides segments v./vi.; the last is between segments ix./x.

The vascular system appears to be chiefly remarkable for the fact that there are only two large transverse vessels uniting the ventral and dorsal trunks; these lie in segments $\mathrm{x}$. and xi., and have distinctly muscular walls; they are very conspicuous in the living worm.

The alimentary canal is, as has been already remarked, 
entirely without a gizzard. The septal glands are well developed, and extend back as far as segment vii.; they have the same structure as in other Oligochæta.

In the ninth segment is, as in all the other species of the genus, a single median diverticulum of the œsophagus. I have reserved the description of this organ till now, as it happened to be better preserved in this species than in the two foregoing. I believe that the structure is identical in the other species; it certainly is in the next two. The pouch is egg-shaped, the creal extremity being directed forwards. There is no trace that I could detect of a formation of the pouch out of two halves; it is a single structure accurately median in position.

The septum separating segments ix./x. closely invests the pouch ventrally, so closely that it is easy to mistake it for the actual walls of the pouch. The real wall of the pouch is excessively delicate, consisting of a fine nucleated membrane which represents the peritoneum. The lumen of the pouch is, where it communicates with the osophagus, very narrow ; it then becomes wider and afterwards narrower again. The lining epithelium is different in character from the œsophageal epithelium, as may be seen in the accompanying figure (fig. 2). This epithelium appears to be composed of very narrow and close-set cells; in a given section but few of these, in relation to their total number, were furnished with a nucleus. This leads me to infer that the cells are considerably broader in one direction than in another, that they have in fact the form of longish narrow plates. This epithelial sac is not immediately surrounded by the delicate peritoneal investment of the organ already referred to. Between the two lies a mass of cells (fig. 2), which forms the bulk of the organ. That this mass, which lies between the outer investment and its epithelial lining, is composed of cells, can only be inferred by the presence of numerous nuclei; no cell boundaries whatsoever could be detected. The nuclei in question are numerous, small, and darkly staining. The faintly staining substance, in which they are imbedded, has a distinctly reticulated appearance-not perhaps quite so coarse as is shown in the figure. It is traversed by numerous blood-vessels, which arise either directly from the peri-œsophageal blood-plexus, or indirectly from a sinus itself in communication with that plexus, but lying beneath as well as above the epithelial lining of the pouch. These capillaries, which are very abundant, collect to form a blood-vessel lying on the ventral side of the calciferous pouch. This vessel corresponds to the pair of 
similarly placed vessels which occur in the Eudrilidæ. The calciferous pouch is thus very vascular, fully as much so as the tract of œsophagus from which it arises. This, however, is not all that I have to say about the minute structure of this organ. The lumen of the pouch does not end blindly a little way in front of the cæcal extremity of the pouch; it is prolonged up to nearly the end, becoming gradually narrower. Just before the extremity of the gland it becomes slightly wider, and communicates with a network of fine tubes spread over the greater part of the periphery of the gland. These tubes have an intra-cellular lumen. They lie just below the blood-vessel which collects and carries away the blood from the pouch, and are of such small calibre as to be very inconspicuous. They are shown in fig. 2 in a longitudinal and vertical section of the pouch. Fig. 3 represents a portion of the network seen in tangential section through a portion of the periphery of the pouch. Both these figures show a structural feature of great interest if it proves to be as in those drawings. Fig. 3 is a drawing which $\mathrm{I}$ have endeavoured to make as accurate as possible of a portion of the network referred to. Fig. 8 is a compound figure of which the details have been filled in from more than one section. In fig. 3 the network is shown to be continuous with a tube (a), which is part of the nephridium of the ninth segment. I confess at once that only one specimen out of six series of sections of this and the following species shows the connexion between the nephridium and the intra-cellular network of the calciferous pouch. But I can see no reason for doubting the accuracy of my drawing; moreover in the other sections there were no appearances in any way opposed to this interpretation. If confirmed, this fact is evidently of some importance. I ought to mention, however, that the nephridia of the ninth segment, which I believe to be connected with the calciferous pouch, also open on to the exterior in the usual way. Before treating further of the connexion of the nephridia with the pouch, I may compare the pouch with similar structures in other Oligochæta.

Calciferous glands, esophageal glands, or glands of Morren, as they have been variously termed, exist in nearly all earthworms. The only family from which these structures are consistently absent is that of the Perichætidæ. Among the lower Oligochæta the Enchytreidæ alone possess similar glands. Ur. Michaelsen, of Hamburg, distinguishes two kinds of these glands in earthworms, which he calls respectively "Kalkdrüsen" and "Chylustaschen." To the latter belong. the unpaired median pouches of the Eudrilidæ, which were 
first described by myself * in the genus Eudrilus. These diverticula of the gut, Dr. Michaelsen supposes, as well as the corresponding organs of the Enchytreidæ, serve not to pour any secretion into the gut, but to absorb digested food. Thus their function would be different from that of the calciferous glands; it is well known that these latter produce a secretion consisting of crystals of carbonate of lime. The difference in outward appearance between the paired calciferous glands and the unpaired ventral pouches of Eudrilus and other Eudrilids is sufficiently striking to suggest a different function. 'The differences in histological structure do not appear to me to be so great. But in a specimen of Eudrilus recently examined by me the median pouches contained large crystals quite similar in appearance to the crystals found in the paired glands. I did not test them chemically. I am disposed to think that the two kinds of glands really belong to the same category. It will be noticed that they do not co-exist in the same segment. As to one series of glands being paired, the other unpaired, I do not attribute much importance to this. Neither does Dr. Michaelsen; for he places in the same category with the "Chylustaschen" of Eudrilus \&c. the paired diverticula of Pygmooodrilus.

In the Enchytreidæ, moreover, they may be paired or unpaired. For this reason I do not lay much stress upon the existence of these ventral median pouches in Gordiodrilus as evidence of a close affinity with the Eudrilidæ. In a recent paper $\dagger$ I have described the branched and anastomosing lumen of two Eudrilids, viz. Heliodrilus and Hyperiodrilus, to be at the periphery of the organ intracellular. This appeared to me to be a necessary result of the folding: and refolding of the lining membrane. In Gordiodrilus, however, it is different; I should rather compare the intracellular part of the gland with the dorsal median diverticulum of Buchholtzia $\ddagger$. If a glandular structure has an intracellular system of ducts, one is tempted without more ado to put it down as of nephridial nature. Avoiding any undue prejudice of this kind there still remains the actual connexion of the intracellular part of the gland-pouch in Gordiodrilus with a nephridium. It may be, as was suggested to me, an unimportant matter due to the absorption of the intervening:

* "Contributions to the Anatomy of Earthworms," Proc. Zool, Soc. 1887, p. 273 .

† "On the Structure of two new Genera of Earthworms, \&c.," Quart. Journ. Micr. Sci. vol. xxxii. p. 235.

† Michaelsen, “Ueber Chylusgefässsystem bei Enchytræiden," Arch. mikr. Anat. Bd. xxviii. p. 292. 
wall; if the facts of this connexion are of morphological importance, and not the result of a mere accident, they are evidence that the œsophageal glands, like the "salivary glands" (mucous glands of Acanthodrilus \&c.) and the anal glands in A canthrodrilus multiporus, are partly at least formed out of nephridia. The glands appended to the alimentary tract of Oligochæta would thus be for the greater part reducible to a common origin.

The nephridia of this species are enveloped in a very thick layer of peritoneal cells; there is no terminal vesicle at the extremity of the nephridium ; the funnel opens as usual into the segment in front. The first nephridium is in the fourth segment; they continue thence without any interruption to the end of the body. The thick coating of peritoneal cells is found in all the species of Gordiodrilus, and gives to them their whitish colour. The cells are in so many cases loaded with spherical granules that not only the nucleus but sometimes the limiting membrane is concealed; some of these granules are, others are not, stained by the colouring reagent used. The anterior nephridia have not this thick coating of vesicular cells; the segment in which this investment is first apparent seems to vary. In one individual the nephridia of segment xiii. were the first to show an increased development of the peritoneum; in another I did not find these granular cells before the nephridia of segment xix.

The reproductive organs of this species are constructed upon the same plan as in other species. The testes are two pairs, in segments x., xi.; the ovaries a single pair, in xiii. There are no receptacula ovorum, and the oviducts have the usual relations. 'The sperm-sacs occupy segments ix.-xii. I need say nothing about the vasa deferentia and atria.

The spermatothecæ, on the other hand, are a little different from those of other species. The form and minute structure of one of these organs is illustrated in fig. 7, which represents a longitudinal section through the entire pouch, and is naturally compiled from a number of sections. The pouch (there are two pairs, in segments vii., viii.) consists of two parts, firstly of a wide cæcal pouch, secondly of a narrow duct connecting this with the exterior. At the junction of the two is a pair of small diverticula, one on each side. One of these two is longer than the other, though both are in point of size rudimentary. The distal pouch is round or oval in form and thin-walled; it is lined by columnar epithelial cells and covered externally by a thinnish layer of fibrous appearance with interspersed nuclei. In the diverticula the cells are lower. There was no indication of the function which the 
diverticula perform, as the pouch was quite devoid of sperm. I have often pointed out that, when diverticula are present, the sperm is nearly, if not quite, invariably stored in them and absent from the main pouch. The epithelium also of the diverticula is commonly different in structure from that of the pouch into which the diverticula open. However, there was nothing of this kind to be observed in Gordiodrilus elegans. Between the points where the diverticula open and the exterior the spermatotheca is narrow; but this narrower portion is by no means so long as it is in Gordiodrilus robustus (cf. figs. 4 and 7 ). It is ensheathed by a very thick layer of muscles, which are arranged in two directions. There is a single layer of stoutish fibres which pass round the tube and must act as a compressor, serving perhaps to eject the sperm. This layer of muscles, as shown in the figure, is not in contact with the lining epithelium of the tube. Whether this is or is not due to reagents I am unable to say. It suggests the possibility of a protrusion of the pouch. The outer layer of muscles is thick; it has a longitudinal direction, and in contracting would tend to protrude the pouch. Outside the two muscular layers is the peritoneal layer, which has the appearance of connective tissue and is provided with numerous nuclei; it is this layer alone which covers the pouch distally.

\section{Gordiodrilus ditheca, sp. n.}

(Pl. VII. fig. 8.)

Among the specimens of the last species was a single individual which showed an interesting difference from the others. 'There was only a single pair of atria present, and in correspondence with these only a single pair of spermatothecæ. In other respects the individual agreed absolutely with Gordiodrilus elegans.

The question is whether the absence of the atria of segment xvii. and of the spermatothecæ of segment viii. constitutes a specific character. It might possibly be regarded as merely a variation. This case is quite analogous to that of the earthworm which I described some years ago * under the name of Neodrilus monocystis. That worm agreed in almost every particular with Acanthodrilus dissimilis, including even the remarkable alternation from segment to segment of the nephridiopores. It only differed in having but one pair of atria and one pair of spermatothecæ. But the spermatothecæ

* "Observations on the Structural Characters of certain new or littleknown Earthworms," Proc. Roy. Soc. Edin. 1887, p. 157. 
differed in the form of the diverticulum. My description of Neodrilus has recently * been confirmed and extended by Mr. Benham, and I myself have since received additional examples. It is clearly a distinct species, but not, as I now think, a distinct genus. Both this instance and that afforded by Gordiodrilus ditheca seem to show that the doubling of the atria is not quite so important a character as I and others have been hitherto inclined to regard it. The possession of one or of two pairs of atria need not, as I now think, hinder species from being placed in the same family, or even genus, if their other characters support such a juxtaposition.

\section{Gordiodrilus dominicensis, sp. n.} (Pl. VI. figs. 2, 3.)

Of this species I have received about half a dozen examples from Kew ; the habitat of the worm is the island of Dominica, in the West Indies.

The worms were all of the same size; one selected for measurement was 26 millim. in length by a breadth (at the head end) of 1 millim. It consisted of about eighty segments. The species is of the same build as Gordiodrilus elegans; and so alike are they in external characters that at first I thought that I was dealing with the latter species. It will be seen, however, from the following description that they are by no means identical.

\section{External Characters.}

The setæare strictly paired and of the usual Lumbricid pattern. They are not modified in size or shape anywhere. Only the veritral pairs are absent upon the xviiith and xixth segments where the atrial pores open. The anterior segments are narrower-have a less antero-posterior diameterthan those which follow; from and including the seventh segment each is divided by a furrow into two parts. This furrow as nearly as possible coincides in position with the setæ. Further back still the segments are marked by more numerous furrows.

The prostomium is continued by furrows to nearly the posterior boundary of the buccal segment.

The nephridiopores are in front of the lateral pair of setæ; they can usually be fixed to one or other of the two setæo of the pair, and in fact show an alternation in position; some-

* "Notes on Two Acanthodriloid Earthworms from New Zealand, Q. J. M. S. vol. xxxiii. p. 289. 
times they are in front of the outermost of the two setre, sometimes in front of the innermost.

The atrial pores are, as in Gordiodrilus elegans, upon segments xviii. and xix. From these segments the ventral pairs of setæ have disappeared. The pores are borne upon two projecting folds of epithelium, which seem to have much the same structure as in the last species. The external characters are thus hardly different from those of Gordiodrilus elegans.

\section{Internal Structure.}

The internal structure, while agreeing in most particulars with that of the last-mentioned species, presents nevertheless quite recognizable points of difference.

In the alimentary canal the buccal cavity occupies the first two segments and a part of the third. The supra-œesophageal ganglia which lie in the third segment mark the commencement of the pharynx; the pharynx has, as usual, a strongly muscular dorsal wall and occupies only one segment-the fourth. The osophagus passes from here to the xiiith segment, in which the intestine commences, and is divisible into two regions. The first part, occupying segments iv.-viii. inclusive, is very slightly vascular and the epithelial lining is much folded; after the viiith segment the walls of the œesophagus are very vascular and not so much folded; but this latter character, though it occurred in two specimens examined, may be perhaps accidental. If I had dissected the worm only, instead of seeking the results obtained by dissection by a continuous series of longitudinal sections, I should have put down the pharynx as occupying a much larger number of segments than one. The tract of esophagus in fact which immediately follows the pharynx is covered dorsally with a dense mass of septal glands ; these are absent from the pharynx itself. These septal glands, which are so common among the lower Oligochæta, extend back as far as the viith segment, and there are traces of them in the viiith; but it is only in the vth segment that they form a dense investment of the gut. In the ninth segment the œsophagus gives off the single ventral diverticulum which distinguishes this from any other genus of Oligochæta.

The relations of the calciferous pouch are precisely as in the last species; in fact the description I have already given of this body was largely drawn from sections of the present species. 
Running along the dorsal side of the œsophagus the supraintestinal vessel first becomes evident in this region of the body. Gordiodrilus dominicensis has the two hearts of segments $\mathrm{x}$. and $\mathrm{xi}$. that are found in other species.

There are three specially thickened septa which separate segments vi./vii., vii./viii., and viii./ix. The septa lying between v./vi. and ix./x. are also tolerably strong.

The nephridia are paired; they commence in the vth segment, and are present in the genital segments. From the tenth segment onwards they are invested, as in the other species of the genus, with a mass of clear peritoneal cells. The funnels opening into the segment in front of that which bears the external aperture were seen. I could find no bloodvessels upon the nephridia either in sections or in teased glycerine preparations of the organs. This statement applies to the other species also.

The reproductive system appears to differ from that of all other species of the genus in the total absence of spermatothecæ. We are at the present time acquainted with several Oligochæta which have no spermatothecæ; for the most part these belong to genera where the spermatotheca are normally present. There is therefore nothing extraordinary in their absence from Gordiodrilus dominicensis, though present in the other species of the genus. The testes are in segments $x$. and xi. In one out of the two or three individuals examined by me there were two pairs of ovaries, though but a single pair of oviducts occupying the usual position.

In other particulars the reproductive organs are quite like those of Gordiodrilus elegans.

It will be clear from the foregoing description that this species differs but slightly from $G$. elegans. 'T'he only wellmarked point of difference is the absence of spermatothecæ. If I have not by some accident overlooked these structures their absence is of course sufficient to separate the two species.

\section{Diagnoses of the Genus and Species.}

From the above anatomical description of the five species of the genus I attempt the following diagnoses :-

\section{Genus GORDIODRILUS, gen. nov.}

Small slender terrestrial Oligochata, with paired setae of the usual Lumbricid pattern. Clitellum variable, always inclu. 
ding the male pores. Nephridia paired, and after the first few surrounded by a thick mass of peritoneal cells. Alimentary canal with a single median ventral diverticulum in segment ix. ; gizzard generally absent; intestine without typhlosole. No subnervian vessel; two pairs of stout hearts in $x$., $x i$. Testes in $x$., xi., or $x$. only; atria two pairs (or one pair), with an epithelial lining only one cell thick opening on to two consecutive segments; vasa deferentia opening independently of atria; ovaries in xiii.; spermatothecce two pairs (or one pair) in vii., viii., with no diverticula, or at most rudimentary diverticula. No penial seta.

\section{Gordiodrilus tenuis, sp. n.}

Ventral setce much larger than dorsal. Clitellum xiv.xxvii. Male pores on xx. and sixi. One pair of testes.

\section{Gordiodrilus robustus, sp. n.}

Male pores on xvii. and xviii. A median genital papillu on xix. Gizzard present.

\section{Gordiodrilus elegans, sp. n.}

Male pores on xviii. and xix. Clitellum xiii.-xix. Spermatotheca with rudimentary diverticula.

\section{Gordiodrilus ditheca, sp. n.}

Male pores on xviii. only. One pair of spermatothece in vii., without diverticula.

\section{Gordiodrilus dominicensis, sp. n.}

Male pores on xviii. and xix. No spermatotheca.

The following table shows the principal resemblances and differences between the five species:- 
new Genus of Oligochata.

\begin{tabular}{|c|c|c|c|c|c|}
\hline 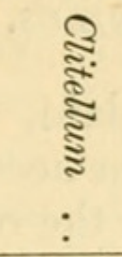 & 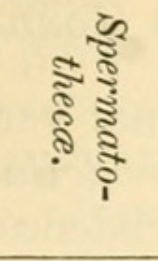 & $\begin{array}{l}\stackrel{A}{5} \\
\text { ลे. } \\
\vdots \\
\vdots\end{array}$ & 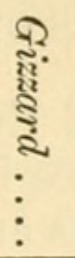 & $\begin{array}{l}\frac{{ }^{2}}{2} \\
\vdots \\
\vdots\end{array}$ & \\
\hline 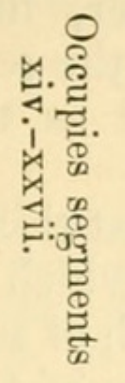 & 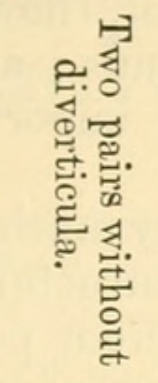 & 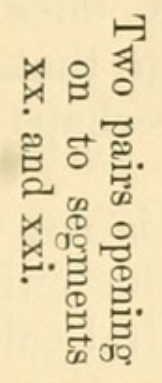 & 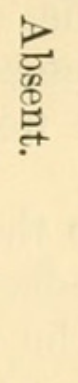 & 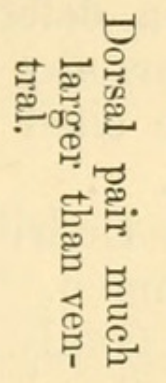 & 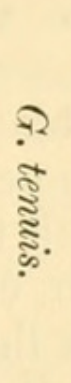 \\
\hline 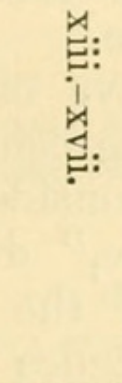 & 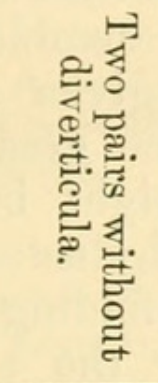 & 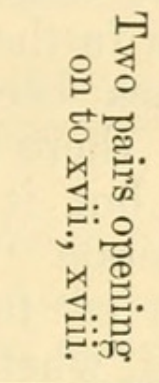 & 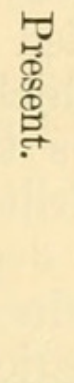 & 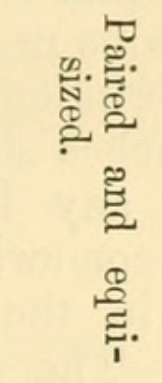 & 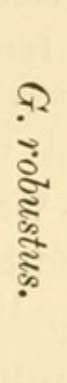 \\
\hline $\begin{array}{l}\text { 峛: } \\
\vdots \\
\vdots \\
\vdots \\
\vdots \\
\vdots\end{array}$ & 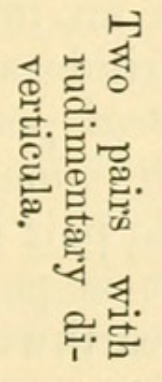 & 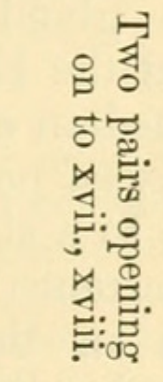 & 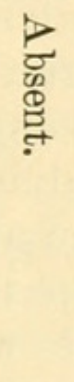 & 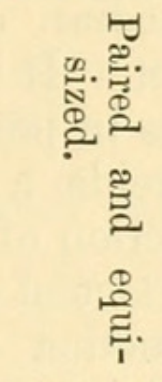 & 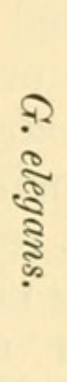 \\
\hline 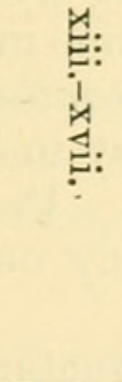 & 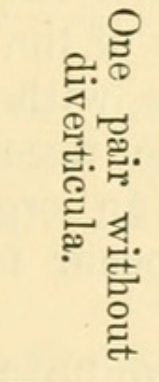 & 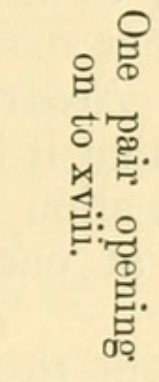 & 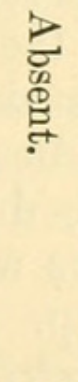 & 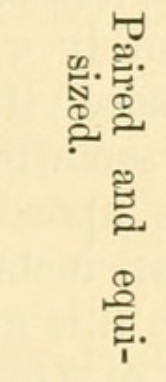 & 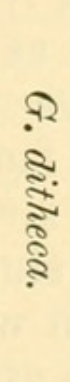 \\
\hline $\begin{array}{l}\text { 峛: } \\
\vdots \\
1 \\
\vdots \\
\vdots \\
\vdots\end{array}$ & $\begin{array}{l}0 \\
\vdots \\
0 \\
0 \\
0 \\
\vdots \\
\vdots\end{array}$ & 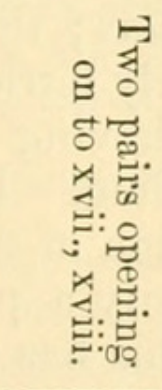 & $\begin{array}{l}z \\
0 \\
0 \\
0 \\
0 \\
\vdots \\
0\end{array}$ & 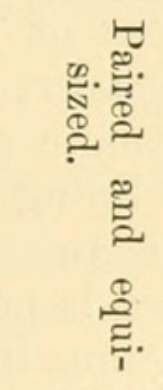 & 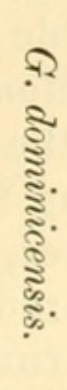 \\
\hline
\end{tabular}




\section{Affinities of the Genus Gordododilus.}

The relationships of this genus are not very plain. I was at first disposed to place it near Acanthodrilus, on account of the double atrial pores and the independence of the opening of the vasa deferentia. It does not, however, in other respects show any likeness to that genus; and the points of resemblance cited are not perhaps so important as they at first appear.

With the Eudrilidæ there is not very much that this genus has in common. Indeed the only structure which at all recalls that family is the ventral calciferous pouch of segment ix., unless, that is to say, the large ventral setæ of Gordiodrilus tenuis be regarded as a further resemblance.

The description which has been given above of these ventral pouches shows that there is no great agreement in detail with any Eudrilid; but it might be considered to represent a somewhat degenerate "Chylustasche," differing principally in the reduction of the folding of the lining membrane. The question is, whether the existence of the unpaired median calciferous gland is an important resemblance or not. It is true that the Eudrilidæ alone agree with Gordiodrilus in possessing median ventral pouches. Among. the Enchytreidæ a median dorsal pouch is met with.

The reduction of the atria to a single pair in Gordiodrilus ditheca is a fact of some importance: it is paralleled by the similar reduction met with in the earthworm named by myself Neodrilus monocystis; in all other respects G. ditheca agrees as closely with the other species of the genus in which I have placed it as does Neodrilus with Acanthodrilus. These facts seem to indicate that it is not necessary to lay too much stress upon the duplication of an organ. Plenty of other similar instances will at once occur to any one conversant with this group.

The atria of Gordiodrilus in their minute structure most resemble those of Ocnerodrilus; these two genera, together with Moniligaster, are the only terricolous forms which agree with the aquatic genera in having but a single row of cells forming the lining of the atrium. I am inclined to believe, however, that the simplification of the structure of the atrium thus produced is not necessarily a proof of affinity with the only other genus in which this has taken place in an exactly similar way; but as in other respects the genera Gordiodrilus and Ocnerodrilus are not far apart, and as they must both be undoubtedly referred to the large family Crypto- 
drilidæ, it seems on the whole probable that they are nearly akin. Provisionally therefore I include the new genus described in the present paper in the family Ocnerodrilidæ. I am not at all certain, however, that the likeness is not the result of a convergence due to simplification in the same direction. Both Ocnerodrilus and Gordiodrilus are chiefly to be defined by negative characters.

\section{EXPLANATION OF THE PLATES.}

\section{Plate VI.}

Fig. 1. Gordiodrilus elegans. Ventral surface of genital segments represented as being semitransparent. at, atria; $v . d$, vas deferens.

Fig. 2. Gordiodrilus dominicensis. Ventral calciferous gland. l, lumen of gland opening into œsophagus ; $n$, nephridium, apparently continuous with intracellular part of lumen of gland; $s$, intersegmental septa.

Fig. 3. The same. A portion of intracellular part of lumen of calciferous gland viewed superficially and showing connexion with nephridium $(n)$.

\section{Plate VII.}

Fig. 4. Gordiodrilus robustus. A spermatotheca.

Fig. 5. The same. Longitudinal section through genital segments, to show external orifice of atria (at.) and vas deferens ( $\left.\sigma^{\circ}\right) . f$, intersegmental furrow; $s$, seta.

Fig. 6. A. Gordiodrilus elegans; B. G. robustus; C. G. tenuis; all of natural size. $\delta$, male pore; $p$, genital papilla.

Fig. 7. Gordiodrilus elegans. Spermatotheca.

Fig. 8. Gordiodrilus ditheca. Longitudinal horizontal section through œsophagus (œs.) and calcilerous gland (Cac.). S, septum; T, testis; H, heart ; Per., peritoneal cells ; $a$, glandular cells surrounding calciferous gland; vac., vacuole.

X.-Notes from the St. Andrews Marine Laboratory (under the Fishery Board for Scotland).--No. XIII. By Prof. M'Intosh, M.D., LL.D., F.R.S., \&c.

\section{[Plate VIII.]}

1. On the Eggs and young Stages of the Sand-eels.

2. On the Ova and Larvæ of certuin Pleuronectids.

3. On Clymene ebiensis, Aud. \& Ed.

4. On the Atlanta-like Larval Mollusk.

1. On the Eggs and young Stages of the Sand-eels.

THE reproduction of the sand-eels has hitherto been involved in obscurity, though considerable attention has been given to the subject at St. Andrews for several years, e. g. by Mr. W. L. Calderwood and others. Similar investigations were carried out elsewhere by the late esteemed and conscientious observer, Ann. \& Mag. N. Hist. Ser. 6. Vol.x. 

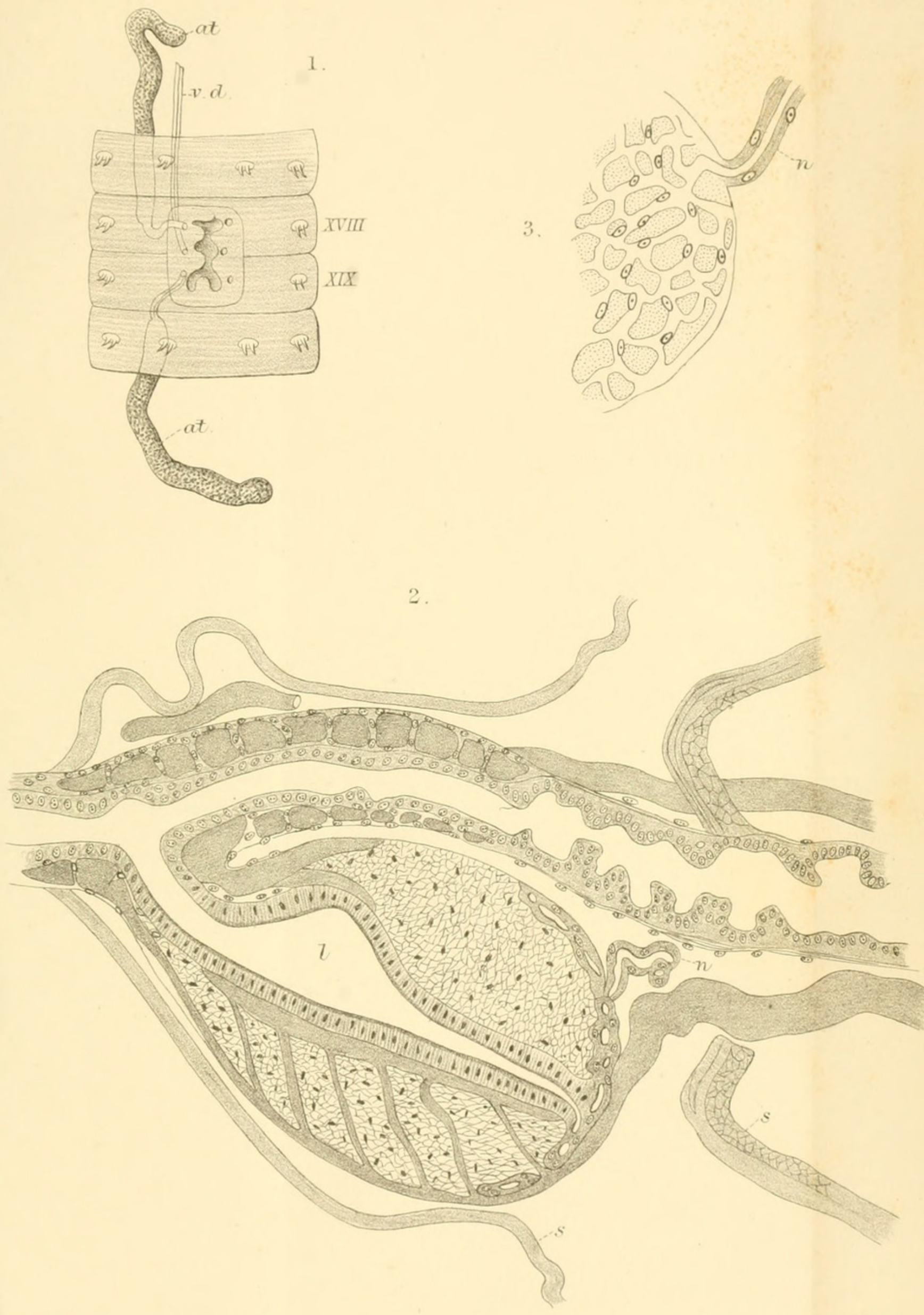
Ann \& Morg. Vat Hist. S. G. Vol. X. Pl. VII.

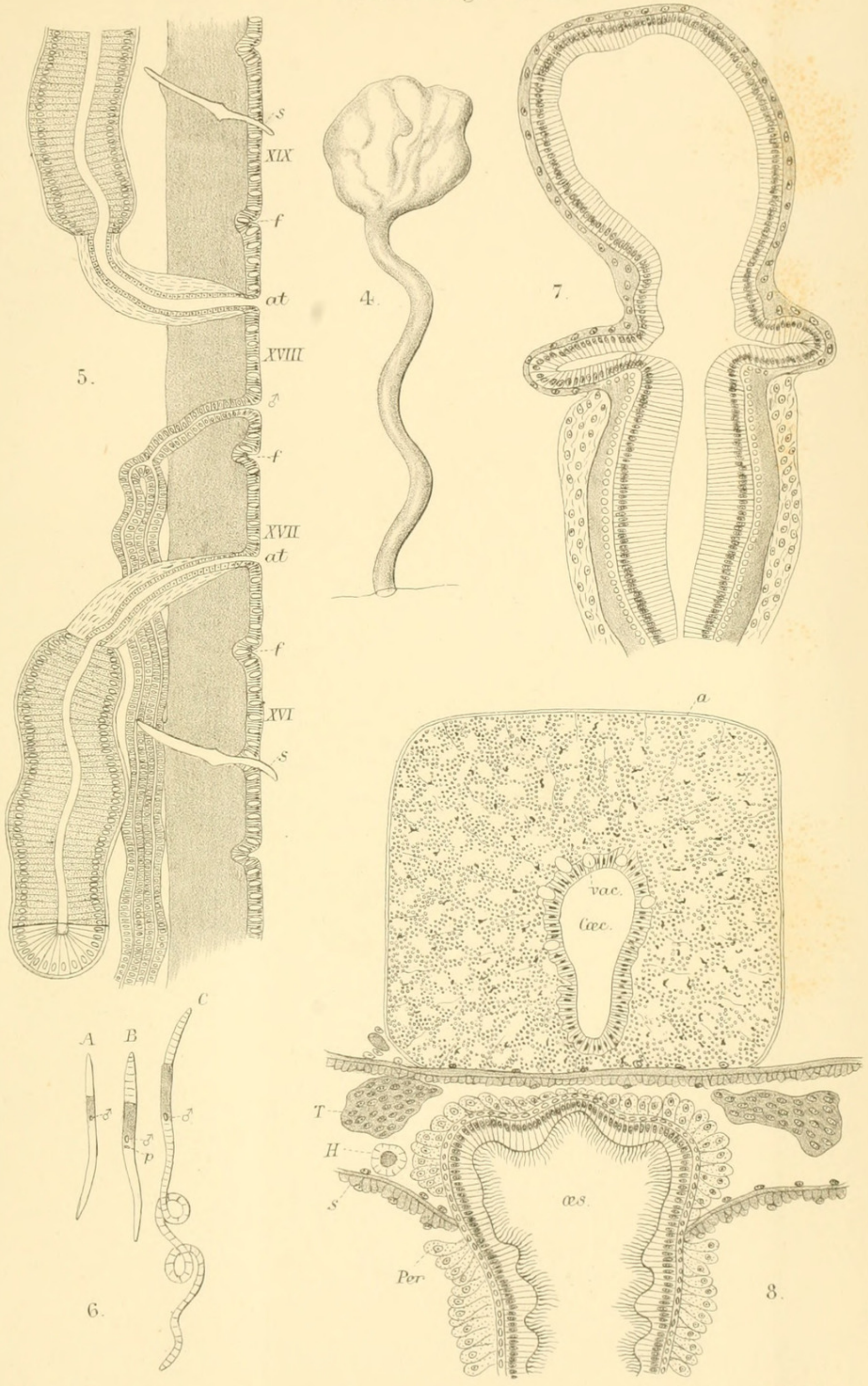

Mintern Bros, hith. 


\section{$2 \mathrm{BHL}$ Biodiversity Heritage Library}

Beddard, Frank E. 1892. "On a new genus of Oligochoeta, comprising five new species provisionally belonging to the Family Ocnerodrilidae." The Annals and magazine of natural history; zoology, botany, and geology 10, 74-97. https://doi.org/10.1080/00222939208677375.

View This Item Online: $\underline{\text { https://www.biodiversitylibrary.org/item/88260 }}$

DOI: https://doi.org/10.1080/00222939208677375

Permalink: $\underline{\text { https://www.biodiversitylibrary.org/partpdf/71955 }}$

\section{Holding Institution}

Smithsonian Libraries

\section{Sponsored by}

Smithsonian

\section{Copyright \& Reuse}

Copyright Status: Public domain. The BHL considers that this work is no longer under copyright protection.

This document was created from content at the Biodiversity Heritage Library, the world's largest open access digital library for biodiversity literature and archives. Visit BHL at https://www.biodiversitylibrary.org. 